\title{
DOMESTICACÃO, CUIDADO E FORMACŨO: O ANIMAL COMO ESPECTRO DA ESCOLA EM VIGIAR E PUNIR
}

\author{
Alexandre Simão de Freitas \\ Universidade Federal de Pernambuco (UFPE), Recife - PE, Brasil
}

RESUMO: O texto aborda uma espécie de genealogia oculta da escola no livro Vigiar e punir do pensador francês Michel Foucault, explorando uma reflexão heterodoxa acerca das relações entre a condição humana e a animalidade. Metodologicamente, o argumento focaliza a abertura da colônia penal de Mettray, em 1840, considerada por Foucault o caso limite de todas as operações do adestramento disciplinar. Mettray foi a primeira escola normal, uma espécie de escola experimental criada para normalizar o próprio poder de normalização. Com Mettray e o seu esforço educativo para disciplinar, sobretudo os disciplinadores, lembra Foucault, conhecemos a generalização de uma forma de poder que não consente mais em perder sequer o que insiste em desqualificar, tomando por um lado o que parece excluir por outro. Palavras-chave: Michel Foucault. Zoopolítica. Escola moderna.

DOMESTICATION, CARE AND EDUCATION: THE ANIMAL AS SPECTRUM SCHOOL IN DISCIPLINE \& PUNISH

ABSTRACT: This paper addresses a kind of hidden genealogy of school in the book Discipline and punish of the French thinker Michel Foucault, exploring an unorthodox thought about the relationship between the human condition and animality. Methodologically, the argument focuses on the opening of the penal colony of Mettray in 1840, considered the limit case of all disciplinary training operations by Foucault. Mettray was the first normal school, a kind of experimental school created to normalize the power of normalization itself. With Mettray and its educational effort to discipline, mainly the disciplinarian, as mentioned by Foucault, we know the generalization of a form of power that no longer consents to lose even what it insists on disqualifying, taking on one side what it seems to exclude on the other. Keywords: Michel Foucault. Zoopolitics. Modern school.

"Doutor em Sociologia pela Universidade Federal de Pernambuco (UFPE). Professor Adjunto do Departamento de Administração Escolar e Planejamento Educacional e do Programa de Pós-Graduação em Educação (PPGE). E-mail: < alexshiva@uol.com.br > . 
Foucault exagera... o bistoriador do exército, o historiador da educação e o bistoriador da medicina dificilmente aceitarão o quadro que Foucault pinta de uma disciplina generalizada [...].

José Guilherme Merquior (1985)

\section{INTRODUÇÃO}

Foucault foi, não poucas vezes, acusado de agir nas suas pesquisas sobre o poder disciplinar como um cavaleiro bárbaro. A percepção é que suas análises teriam superestimado o processo de normalização na sociedade francesa da primeira metade do século XIX. Por isso, as conclusões de Vigiar e punir foram recebidas principalmente pelos historiadores como incapazes de dar conta da poeira dos fatos.

Ainda hoje, as reações enérgicas suscitadas pela publicação dessa obra indicam o espírito com que o próprio pensamento foucaultiano foi recepcionado, através de um misto ambíguo de admiração e repulsa (BERT, 2014; PERROT, 1980), o que, em certo sentido, explicita, também, o efeito irritante provocado nos leitores desse best-seller inconteste. Em vários momentos, Michel Foucault tentou, quase sempre sem sucesso, explicitar que a tese latente de Vigiar e punir não consistia em desvelar a automaticidade do poder, nem em descrever a mecânica dos dispositivos disciplinares.

Sua preocupação girava em torno de um tema tecnológico relacionado, simultaneamente, ao "nascimento de estruturas institucionais" da sociedade moderna e à gênese "de certas formas de saber" configuradores das ciências humanas (FOUCAULT, 2003, p. 333). Assim, mais do que um mero capítulo da rą̧ão punitiva, suas investigações buscavam problematizar como determinadas práticas constituíram regimes de verdade ainda vigentes. Tratava-se de uma história da objetivação de elementos que os historiadores abordavam como objetivos, uma “objetivação das objetividades” (FOUCAULT, 2003, p. 351).

Essas observações são importantes, sobretudo, quando se considera que foi a partir de Vigiar e punir que se cristalizou a imagem de Foucault como um autor cuja obra, no que tem de essencial, deveria ser lida como uma analítica do poder disciplinar. Segundo Silvio Gallo (2008) e Alfredo Veiga-Neto (2009), esse tipo de compreensão contribuiu para delimitar a influência do seu pensamento no campo educacional. De fato, à sombra da edição brasileira de Vigiar e punir, em 1977, produziram-se vários trabalhos que privilegiaram a questão do 
disciplinamento, cristalizando a imagem que os educadores ainda fazem de Foucault. Nesse sentido, as respostas fornecidas pelo pensador francês aos seus críticos historiadores devem servir de anteparo ao argumento que pretendemos colocar em jogo nessa reflexão que tem como horizonte mais amplo as comemorações recentes e releituras abertas pelos quarenta anos do seu livro mais comentado.

Mas, contrariando a percepção de que, no Brasil, teria ocorrido uma "leitura vassala" de Vigiar e punir (OLIVEIRA, 2011, p. 315), o presente texto assume que mesmo as análises consideradas exageradas se constituem como um marco incontornável para o campo educacional brasileiro, na medida em que permitem escavar o subsolo escamoso de várias das nossas convicções pedagógicas. Assim, se é verdade que os historiadores da educação, da medicina ou do exército aceitaram apenas a contragosto as conclusões de Vigiar e punir, isso ocorreu porque Foucault (2003, p. 235) evitou reduzir suas análises aos domínios disputados pelos "especialistas de cada período [que] tal como crianças bochechudas se acotovelam em torno de um bolo de aniversário".

Assim, o propósito mais amplo desse texto consiste em mostrar como o livro sobre o nascimento da prisão guarda também uma crítica radical à metafísica subjacente aos gestos dominantes nas ciências humanas, em geral, e nas teorias educativas, em particular. Mais diretamente, pretendemos indicar, em Vigiar e punir, uma análise relativa aos nossos humanismos domesticadores, focalizando a própria indicação foucaultiana de que a disciplina se configura como uma arte sutil do bom adestramento.

A partir disso, por nossa conta e risco, desenvolvemos uma reflexão heterodoxa acerca das relações entre a condição humana e a animalidade. Nesse percurso, faremos Foucault pagar uma espécie de dívida: a explicitação da genealogia dos indivíduos considerados como incorrigiveis; genealogia que foi deixada aparentemente inconclusa no curso Os anormais, no mesmo ano de 1975. A genealogia dos incorrigíveis configura-se, a nosso ver, como uma dobradiça fundamental do projeto genealógico foucaultiano, ao articular os processos de normalização disciplinar e a dinâmica regulamentadora da biopolítica, ao mesmo tempo que antecipa algumas premissas subjacentes aos trabalhos finais de Foucault acerca da ética do cuidado de si e da parresia cínica.

$\mathrm{O}$ argumento, contudo, só faz sentido se admitirmos que, na história do nascimento das prisões, reverbera um questionamento acerca do que "ainda domestica o homem" face ao naufrágio dos humanismos (SLOTERDIJK, 1999, p. 32), ou seja, se lermos Vigiar e 
punir, simultaneamente, como uma análise da zoopolítica moderna e um diagnóstico crítico sobre as formas contemporâneas de cuidado e formação do humano.

\section{VIGIAR E PUNIR COMO UMA CRÍTICA À SOCIEDADE DOMESTICADA}

Considerado um marco do pensamento contemporâneo, quarenta anos depois de sua publicação em 1975, Vigiar e Punir parece ainda conservar toda a sua força, "suscitando risos inesperados" (DELEUZE, 2006, p. 33). Nos termos de Deleuze, com essa obra, Foucault nos presenteou com uma nova cartografia. Uma cartografia de guerra movente de vários diagramas dos exercícios do poder: o diagrama-suplício, o diagrama-punição, o diagrama-disciplina. Uma análise cuidadosa desses diagramas apontaria não apenas como o Ocidente penaliza aqueles que não se enquadram em leis e normas, mas desvelaria a emergência de novas práticas de sujeição. Mais: ao descrever a emergência do poder disciplinar, Vigiar e punir expõe o processo de amplificação das forças do corpo em termos econômicos de utilidade, desvelando a subsunção política dessas forças.

O momento histórico das disciplinas fez do corpo uma aptidão e uma capacidade que elas procuram controlar. No entanto, engana-se quem enxerga nessas análises apenas a denúncia de uma espécie de grande maquinação. O propósito almejado visa antes desmontar o suposto humanismo dos reformadores penais, que, na esteira do Esclarecimento, defendiam a prisão como mecanismo ressocializador. Vigiar e punir endereça uma crítica contundente ao imaginário subjacente às teses humanistas desses reformadores, o que leva Foucault (2013, p. 84) a afirmar que "Humanidade" é apenas um nome respeitoso dado a uma nova economia dos delitos e das penas. Com sua ironia habitual, ele se propõe a desconstruir os segredos dessa suposta disposição humanista.

Todos os que leram a transcrição do relato do suplício de Damiens feito pela Gazette d'Amsterdam, em 1757, e que abre o livro Vigiar e punir, relato interrompido pela exposição do regulamento de uma prisão francesa em 1838, não têm dúvidas: o autor dessa obra não está retratando uma evolução ou delineando um progresso da sensibilidade e do pensamento. ${ }^{1}$ A análise indica a emergência de novas práticas ortopédicas. Em nenhum momento se trata de defender um mundo carcerário mais humano, pois o que sustenta as formas de aprisionamento moderno é apenas o "sonho de uma maldade" (FOUCAULT, 2013, p. 197), um delírio cientificista 
articulado à produção de corpos dóceis. Um dos lugares em que esse sonho distópico se encarnou, para além dos quartéis e das fábricas, foi justamente a escola. O poder disciplinar desdobrou formas de encarceramento massivo, pois tinha também em vista educar condutas.

Assim, inicialmente nos Colégios e depois nas escolas primárias, a disciplina se impôs como um verdadeiro regime, articulando um sistema arquitetural e uma utopia capazes de permitir uma ordenação globalizante das multiplicidades humanas, cujo princípio basilar Foucault denomina panoptismo. Em uma sociedade regida pelo panoptismo e suas regras das localizações funcionais, os diversos espaços sociais, que estavam geralmente livres para vários usos, especializam-se para satisfazer uma necessidade estrita de vigilância. A organização da escola moderna aparece aqui, mais uma vez, como um exemplo digno de nota, ao exigir que nela todos os indivíduos sejam localizados em um mesmo lugar. Cada aluno deverá ter

[...] o seu lugar marcado e nenhum o deixará nem trocará sem a ordem e o consentimento do inspetor das escolas. [Assim] será preciso fazer com que aqueles cujos pais são negligentes e têm piolhos fiquem separados dos que são limpos e não os têm, que um escolar leviano e distraído seja colocado entre dois bem comportados e ajuizados, que o libertino ou fique sozinho ou entre dois piedosos. (FOUCAULT, 2013, p. 126)

A escola moderna constitui-se, portanto, como espaço privilegiado de cultivo da arte de pôr os homens enfileirados, pois o conjunto dos alinhamentos escolares (cada aluno segundo a sua idade, desempenho e comportamento) reflete uma série mais ampla de posições que demarcam nossa sociedade de ortopedia generalizada. Ideia que já havia sido exposta por Jeremy Bentham, que Foucault, dessa vez, contrariando os historiadores da filosofia, considera mais importante para o entendimento da modernidade do que Kant ou Hegel. Na escola, diz Bentham (2008, p. 75-76), toda brincadeira, toda conversa, enfim,

[...] toda distração de qualquer tipo, está efetivamente descartada pela situação central e protegida do mestre, secundado pelas partições de telas - tão discretas quanto se queira - entre os estudantes [...]; de forma que a única despesa extra na construção seria com as partições, para as quais uma espessura bastante moderada seria suficiente. As pessoas jovens de ambos os sexos poderiam, por esse meio, dormir, assim como estudar, tanto sob inspeção quanto sozinhas - uma circunstância de não pequena importância aos olhos de muitos pais.

$\mathrm{Na}$ escola, os sujeitos são organizados por partições e igualmente expostos à visão de um "mestre em sua ronda" encarregado de obrigar 
às ocupações: "[...] 8:52 chamada; 8:56 entrada das crianças e oração; 9 horas entrada nos bancos; 9:04 primeira lousa; 9:08 ditado; 9:12 segunda lousa [...] (FOUCAULT, 2013, p. 128). Caberia ao mestre construir um tempo integralmente útil, sem desperdícios, uma vez que a disciplina exige a melhor relação possível entre um gesto e a atitude global do corpo. Foucault lembra, nesse contexto, o aprendizado da caligrafia, o qual supõe um exercício rigoroso, visando "manter o corpo direito, um pouco voltado e solto do lado esquerdo, e algo inclinado para a frente, de maneira que, estando o cotovelo pousado na mesa, o queixo possa ser apoiado na mão" (FOUCAULT, 2013, p. 129). O exemplo é importante, pois visa demonstrar que o alvo do ensino é a postura que os escolares devem manter, corrigindo-a toda vez que dela se afastarem. Justifica-se, assim, a afirmação foucaultiana de que a correta disciplina é, antes de tudo, uma arte do bom adestramento. O poder disciplinar, em vez de se apropriar e de retirar, tem como função maior "adestrar para retirar" e, por essa via, se "apropriar cada vez mais e melhor" (FOUCAULT, 2013, p. 164). Adestra inclusive as multidões confusas, móveis e inúteis.

Desse modo, ao analisar os recursos para o bom adestramento, Foucault elucida por que a emergência de novas estratégias de encarceramento é um fenômeno dependente da difusão massiva de modelos educativos voltados à produção de sujeitos domesticados. Sintomaticamente, a terceira parte da obra, intitulada Disciplina, é atravessada pela análise de textos e experiências acerca de uma pedagogia adestradora em vias de ser escolarizada. ${ }^{2}$ Todos os exemplos estudados mostram o nascimento de uma pedagogia muito minuciosa, que, por meio de corpos localizados, atividades codificadas e aptidões formadas, faz com que o Normal se constitua como princípio de coerção no ensino.

A escola se torna o local de elaboração da pedagogia. E do mesmo modo como o processo do exame hospitalar permitiu a liberação epistemológica da medicina, a era da escola "examinatória" marcou o início de uma pedagogia que funciona como ciência. (FOUCAULT, 2013, p. 179)

Vale destacar que o poder disciplinar se legitima pela identificação programática das funções de punir, curar e ensinar. Pois é em torno dessa junção que, nos termos de Foucault (2013, p. 15), "pululam os novos funcionários da ortopedia moral". O problema educativo chave é como prever a evolução de um dado indivíduo a fim de corrigi-lo de forma segura. A busca desse tipo de saber permitiu desdobrar um conjunto de técnicas e discursos científicos acerca da "alma" humana. 
[Logo] não se deveria dizer que a alma é uma ilusão, ou um efeito ideológico, mas afirmar que ela existe, que tem uma realidade, que é produzida permanentemente, em torno, na superfície, no interior do corpo pelo funcionamento de um poder que se exerce sobre os que são punidos - de uma maneira mais geral sobre os que são vigiados, treinados e corrigidos, sobre os loucos, as crianças, os escolares, sobre os colonizados, sobre os que são fixados a um aparelho de produção e controlados durante toda a existência. [...] sobre ela técnicas e discursos científicos foram edificados; a partir dela, valorizam-se as reivindicações morais do humanismo. (FOUCAULT, 2013, p. 31-32)

Nesse momento, temos que nos colocar à escuta de uma pergunta decisiva, enunciada ao longo de Vigiar e punir: o que aprende o genealogista que tem o cuidado de ouvir os ensinamentos extraídos da analítica do poder disciplinar?

A resposta de Foucault é direta e incisiva: em vez de dar fé à metafísica, o genealogista aprende que nas disciplinas dormita uma preocupação em torno da observação individualizante, da caracterização e da classificação, em tudo análoga à organização analítica da espécie. Em outros termos, o panoptismo prefigura uma zoopolítica. O panóptico é, na verdade, um zoológico real com a diferença de que nele "o animal é substituído pelo homem, a distribuição individual pelo grupamento específico e o rei pela maquinaria de um poder furtivo" (FOUCAULT, 2013, p. 193).

O panóptico é uma máquina de fazer experiências voltadas à modificação de comportamentos. A generalização desse dispositivo é o que permite o desenvolvimento de investigações pedagógicas cruciais, ou seja, capazes de tornar viável a análise das transformações que se podem ou que se buscam obter com os seres humanos.

[...] usando crianças encontradas, ver-se-ia o que acontece quando aos dezesseis ou dezoito anos rapazes e moças se encontram; poder-se-ia verificar se, como pensa Helvetius, qualquer pessoa pode aprender qualquer coisa; criar diversas crianças em diversos sistemas de pensamento, fazer acreditarem que dois e dois não são quatro e que a lua é um queijo, depois juntá-los todos quando tiverem vinte ou vinte e cinco anos; haveria então discussões que valeriam bem os sermões ou as conferências para as quais se gasta tanto dinheiro. (FOUCAULT, 2013, p. 193)

Essa compreensão de Foucault não deixa margens para dúvidas. A analítica do poder disciplinar, desde a emergência da escola moderna, é uma ocasião privilegiada para se fazerem descobertas no campo da metafísica, dando a ver o nascimento do homem do humanismo. As disciplinas fazem a metafísica humanista funcionar de modo efetivo através das mais variadas práticas domesticadoras. Por meio de Vigiar e punir, ele expõe-nos a uma "zoologia das subespécies sociais" (FOUCAULT, 2013, p. 239), abrindo uma reflexão política tão assombrosa quanto inesperada acerca da condição humana. 


\section{VIGIAR E PUNIRDESDE OUTRO PONTO DE VISTA: 0 ANIMAL COMO ESPECTRO DA ESCOLA}

Os leitores de Foucault sabem que Vigiar epunirarticula-se com a genealogia da moral de Nietzsche, mas as razões do argumento são pouco conhecidas ou tematizadas pelo campo educacional brasileiro. Recordemos que, em estado de êxtase, Zaratustra havia contemplado as casas dos homens com seus portões baixos a exigirem dos que pretendiam atravessá-los o ato de se curvarem, o que tornava possível transmutar os lobos em cães, além de converter os próprios homens nos melhores animais domésticos.

As reverberações dessa visão extática persistem como um espectro nas análises de Vigiar e punir. O livro mais conhecido de Foucault aponta como o humanismo burguês prolongou, no tempo, uma tarefa zoopolítica anteriormente delineada por Platão e sua distinção entre animais que adestram e animais que são adestrados. Por isso, a bipartição da vida humana em uma zona em todos os sentidos humana e outra zona assimilável à natureza das bestas fez com que o animal aparecesse como uma espécie de umbral a separar o homem de si mesmo (ESPOSITO, 2011). Nesse contexto, uma das tarefas da escola moderna consiste em formar um sujeito que, cultivado habilidosamente, está destinado a se submeter àquela parte de si que não é dotada de características racionais.

Essa leitura heterodoxa de Vigiar e punir permite extrair da afasia do animal algumas questões decisivas sobre a escola e seus poderes. ${ }^{4} \mathrm{O}$ dispositivo escolar moderno funciona como uma via régia para operar os modos pelos quais traçamos as distinções entre vidas a proteger e vidas a abandonar. Por isso, o discurso humanista tenta, a todo custo, velar o conflito político estruturante de nossas sociedades: o homem cindido do não homem. Giorgio Agamben (2013, p. 53), ampliando, nesse aspecto, as teses foucaultianas acerca da fabricação de corpos dóceis, argumenta que a própria produção do humano exige que a educação isole o não humano no homem. Para o pensador italiano, a metafísica humanista tem aqui um papel educativo chave na medida em que ela se refere precisamente a essa metá que custodia a superação da phýsis animal na direção de uma história humana. Para ele, "a máquina antropológica do humanismo é um dispositivo irônico", encarregado de verificar a ausência para o Homo de uma natureza própria, mantendo-o no limiar de uma suspensão excêntrica entre o animal e o humano.

A metafísica humanista vige como um acontecimento, sempre em curso, uma vez que cabe a ela operar, por meio da cesura 
e da articulação entre o animal e o humano, a própria antropogênese como um espaço efetivo de exclusão. Essa posição é radicalizada por Gabriel Giorgi (2014, p. 11) para quem as imagens da vida animal, nas tradições culturais da América Latina, não representariam, como nas sociedades ocidentais, "un revés sistemático y un otro absoluto de lo humano". Nas culturas ameríndias, a animalidade emerge sempre marcada por uma contiguidade e uma proximidade.

Assim, não seria possível separar com precisão os limites de uma vida humana, limites que podem, inclusive, mudar de lugar no interior dos dispositivos culturais. Diferentemente das nossas sociedades, nas quais os humanos possuem uma mesma natureza e se diferenciam em suas culturas, a maioria das sociedades indígenas admite que as sociedades sejam constituídas por seres que partilham uma mesma espiritualidade (cultura), mas que se diferenciam em seus corpos (natureza). Com isso, elas estabelecem uma diferença ontológica de grau, mas não de natureza. ${ }^{5}$

Esse tipo de pensamento incita os educadores a redescreverem o próprio ponto de vista da escola. Considerando que a animalidade compartilha, quer dizer, faz parte do processo de partilha do próprio do homem, o humano seria passível de experimentar (no sentido pragmático-poiético de fazer a experiência de) sua própria formação, pois, enquanto homem, não é, nem há de ser ou de realizar nenhuma vocação histórica ou espiritual. A escola poderia, então, funcionar como um poder de transcendência paradoxal diante da pobreza de mundo do animal na medida em que, na partilha entre o animal e o humano, ela lidaria com as possibilidades abertas pela própria existência.

Os poderes da escola seriam definidos, nesse caso, não seria tanto pelo que ela pode fazer do humano, mas principalmente pelo que ela poderia não fazer. Aqui, os leitores de ontem e os leitores de hoje de Vigiar e punir se deparam com uma desontologização pragmática dos aparatos escolares, uma espécie de devir-besta da escola. As reflexões foucaultianas atualizariam o ato que fundou a escola moderna enquanto espaço soberano de nomeação e classificação dos seres e dos saberes, suspendendo, mesmo que precariamente, os discursos acoplados às nossas maquinações educativas. A questão da animalidade, pensada desde Vigiar e punir, mostra ainda que, como a figura moderna do homem, a escola disciplinar configura-se como uma invenção recente cuja exaustão talvez mostre seu fim cada vez mais próximo. ${ }^{6}$

Porém, mais interessante é ver nessa obra os elementoschave das pesquisas futuras de Foucault acerca dos processos éticos e 
políticos de subjetivação. Nesse aspecto, é bastante curioso constatar que, em Vigiar e punir, ele já sinaliza o fato de que "somos bem menos gregos [do] que pensamos” (FOUCAULT, 2013, p. 190).

$\mathrm{Na}$ sociedade domesticada, lembra Foucault, cuidado se nomeia disciplina, isto é, operação que se encarrega de um indivíduo adestrando-o para que a alma interiorize a norma como uma segunda natureza, fundamental à segurança da espécie. $\mathrm{O}$ animal figura na anatomopolítica disciplinar como "o vigia do sequestro ontológico do homem" (VACCARO, 2011, p. 52), tornando-o, através da escolarização, disponível para uso. Do que decorre a percepção crítica de Foucault de que o poder pastoral é cheio de cuidados.

\section{DA ARTE DO BOM ADESTRAMENTO A UMA GENEALOGIA OCULTA EM VIGIAR E PUNIR}

Tematizar a escola a partir do enigma da animalidade significa, então, produzir um arrombamento nas categorias que fundam nossos humanismos domesticadores. A sujeição disciplinar seria a face velada, melhor dizendo, despistada das narrativas antropometafísicas. Desse modo, a análise dos processos de domesticação em Vigiar e punir coloca-nos diante de um resto, uma ausência agora positivada: a prometida e aparentemente não consumada genealogia dos incorrigiveis.

Essa espécie singularíssima de seres infames, mais do que o monstro humano e o masturbador, constitui-se no alvo privilegiado dos processos de disciplinarização movidos desde o aparato escolar. A incorrigibilidade do incorrigivel requer certo número de intervenções, na verdade, sobreintervenções em relação às técnicas comuns de educação. A incorrigibilidade é uma espécie de monstruosidade diáfana, funcionando como a base de uma etiologia geral das piores singularidades. Por isso, os métodos pedagógicos convencionais são ineficazes quando endereçados aos incorrigíveis, uma vez que eles têm como característica ser "regular na irregularidade" (FOUCAULT, 2006, p. 72). Essa inclusive é uma das razões de o saber em torno do incorrigível só se construir muito lentamente, embora, aos poucos, ele vá se tornar o suporte privilegiado das variadas instituições encarregadas modernas de cuidar e formar o humano.

A incorrigibilidade configura-se como um "estado" relativo à constituição da identidade de um indivíduo ou grupo. O estado é fundo causal permanente, pois quem é sujeito a um estado não é um indivíduo qualquer, já que pode produzir qualquer coisa a qualquer momento. Uma deformidade, um distúrbio funcional, um ato de delinquência, uma embriaguez, tudo que pode ser patológico ou desviante, no 
comportamento ou no corpo, pode ser virtual ou efetivamente produzido a partir de um estado. Mas não é só isso. Os portadores de um estado podem transmiti-lo a seus herdeiros, da maneira mais aleatória possível, o que tem consequências sociais imprevisíveis.

Por essa razão, os incorrigíveis são os portadores privilegiados do perigo. A regulamentação dos incorrigíveis exige dos dispositivos escolares um saber classificatório específico acerca dos modos de vida desclassificada. ${ }^{7}$ Os incorrigíveis não seriam capazes de observar os princípios subjacentes às leis e ao pacto social. O educador deveria, portanto, transportar-se "para dentro" dele, "a fim de penetrar sua alma", estudando "seu espírito, seus costumes, sua idade" (FOUCAULT, 2006, p. 116).

A discussão em torno da educação dos incorrigíveis, nomeados agora como os delinquentes, adquire centralidade na parte final de Vigiar e punir. Mas, antes de tudo, para Foucault (2013, p. 238), o delinquente não deve ser confundido com o infrator. O que caracteriza o delinquente não é tanto seu ato, quanto sua vida. Logo, os processos educativos que lhes são endereçados precisariam totalizar, quer dizer, envolver completamente a existência desses seres singulares. Suas histórias de vida deveriam revelar a formação do seu caráter. A investigação biográfica precisaria reconstituir a vida desses seres infames, configurando-se, ela mesma como uma técnica formadora de uma existência retreinada. Assim, a eficácia da educação, nesse âmbito, dependeria diretamente do escrutínio minucioso da vida dos delinquentes. Uma tarefa prioritária da pedagogia direcionada aos delinquentes consiste em desenhar tipologias sistemáticas, como a que é retomada e analisada por Foucault da obra de G. Ferrus, Des prisonniers.

Essa obra apresenta uma classificação próprias aos delinquentes. Em primeiro lugar, os que são dotados de recursos intelectuais considerados superiores à média, mas que são perversos, ou por uma predisposição inata, ou por uma moral iníqua. Para esses, indicavase um isolamento completo. Um segundo grupo era formado pelos que são levados ao crime por sua inaptidão ou incapacidade para o pensamento e para o trabalho. Esses deveriam viver em pequenos grupos, sendo estimulados por ocupações coletivas e submetidos a uma vigilância permanente. Por fim, haveria os delinquentes que se deixam arrastar para o crime por preguiça e por falta de resistência às más inclinações. É justamente a esses que convém mais educação que repressão, mais vigilância e disciplina do que castigos. Assim, essas classificações quase etnográficas das vidas delinquentes, bem como o debate em torno da melhor maneira de educá-los, serviram 
para unificar as duas linhas, antes divergentes, de objetivação do criminoso: os monstros morais ou políticos e o infrator jurídico. A conclusão sintetizada por Foucault ainda hoje nos alcança.

Para ele, a generalização do dispositivo prisional é inseparável de todo um conjunto de práticas educativas planejadas para lidar com esses indivíduos. O que inquieta os leitores de Vigiar e punir, contudo, não é a afirmação de que "a prisão fabrica [os] delinquentes" (FOUCAULT, 2013, p. 241), tampouco a descrição dos princípios da "boa condição penitenciária" (FOUCAULT, 2013, p. 255), mas o modo como, ao longo da última parte dessa obra, é desvelada a produção de toda uma gestão positivada das ilegalidades, cuja economia geral mal esconde seus usos políticos e, por que não dizer, pedagógicos.

Percebe-se, com clareza, o estreitamento dos seus críticos, uma vez que as análises conclusivas de Vigiar e punir, menos que negar os processos de resistência às disciplinas, contribuem para mostrar como a produção da delinquência disseminou um processo generalizado de moralização das condutas, principalmente junto às classes populares, que se viram privadas do seu próprio poder de revolta. ${ }^{8} \mathrm{O}$ poder disciplinar, na ótica de Foucault, nunca deixou de suscitar as mais variadas formas de resistências. A disciplina sempre encontrou "problemas a resolver", problemas para os quais a antiga economia do poder não estava aparelhada.

\footnotetext{
[A disciplina] pode fazer diminuir a 'desutilidade' dos fenômenos de massa; reduzir aquilo que, numa multiplicidade, faz com que esta seja muito menos manejável que uma unidade; reduzir o que se opõe à utilização de cada um de seus elementos e de sua soma; reduzir tudo o que nela possa anular as vantagens do número; é por isso que a disciplina fixa; ela imobiliza ou regulamenta os movimentos; resolve as confusões, as aglomerações compactas sobre as circulações incertas, a repartições calculadas. (FOUCAULT, 2013, p. 207)
}

Mas, fundamentalmente, a disciplina tinha como desafio regulamentar as forças que se formam a partir da constituição de toda multiplicidade organizada, ou seja, neutralizar os efeitos de contrapoder que daí nasce e que cria resistência: as agitações, as revoltas, os conluios. É nesse contexto que o controle intermitente das resistências ao poder domesticador das disciplinas exige, por um lado, que o delinquente se torne um indivíduo a conhecer e, por outro, que se construa uma barreira entre os delinquentes e as camadas populares "de que saiam e com as quais permaneciam ligados" (FOUCAULT, 2013, p. 270), principalmente nos meios urbanos das grandes cidades.

O poder disciplinar revela aqui sua forma mais astuciosa, pois moralizar as classes populares é uma tarefa importante, tanto 
econômica, quanto politicamente. A hostilidade quanto aos delinquentes configurou-se como uma estratégia capilarizada de educação política bastante eficaz, rompendo a relação entre os delinquentes e as camadas populares e incitando uma batalha surda contra a "pobreza-dissipaçãopreguiça-bebedeira-vício-roubo-crime" (FOUCAULT, 2013, p. 272). Desse combate participaram filantropos de todo tipo, empenhados em impedir que a monstruosidade criminosa fizesse "cair todo o seu escândalo" sobre os pobres (FOUCAULT, 2013,p. 274). ${ }^{9}$ Um verdadeiro exército de educadores foi, então, convocado para lidar menos com a infração do que com as "pequenas indisciplinas" (a preguiça, a despreocupação, a devassidão). Os incorrigíveis, como ressaltamos, sempre estiveram na base dessas pequenas delinquências, múltiplas e viscosas, com as quais se acusa pedagogicamente a civilização inteira e que forneceram a Foucault o horizonte mais amplo de inteligibilidade da forma disciplina no seu estado mais intenso.

Por isso, não casualmente, os seus olhos se voltam, no capítulo final de Vigiar e punir, para uma data considerada emblemática: 22 de janeiro de 1840. Nessa data, diz ele, "se completa a formação do sistema carcerário". Essa data, que não é senão aquele dia de "uma glória de um calendário" (FOUCAULT, 2013, p. 278), demarca a abertura oficial da colônia penal de Mettray. Em Mettray, uma espécie de prisão falba, eram detidos jovens citados nos tribunais, mas absolvidos em virtude do artigo 66 do Código Penal. Para Foucault, essa colônia penal constituiu-se como o símbolo maior de uma série de instituições que se colocavam na fronteira do direito penal, formando o que ele passaria a denominar de o arquipélago carcerário. Nessa colônia, ele se deparou com o modelo em que se concentraram todas as tecnologias coercitivas do comportamento.

Em Mettray, foram unificados os cinco modelos de referência na base do novo poder punitivo: o modelo da família, do exército, da oficina, da escola e o modelo judiciário. Simultaneamente claustro, prisão, quartel, oficina e colégio, a colônia de Mettray permitiu a Foucault (2013, p. 279) determinar a especificidade da função de adestramento. Os chefes e subchefes de Mettray não eram "nem juízes, nem professores, nem contramestres, nem suboficiais, nem pais, mas um pouco de tudo isso".

Um pouco de tudo isso, na medida em que aí estavam sendo preparados os novos engenheiros da conduta e os ortopedistas da individualidade. A colônia de Mettray foi o caso-limite de todas as operações do adestramento disciplinar. Mas nela o "elemento essencial" está no fato de serem aplicados aos futuros administradores 
os mesmos aprendizados e coerções que seriam impostos aos jovens detentos. Trata-se da primeira "escola normal" da disciplina pura. Pois

[...] essa superposição de modelos diferentes permite determinar a função de 'adestramento' no que ela tem de específico. [...] Adestramento que é acompanhado por uma observação permanente [...] um saber organizado como instrumento de apreciação perpétua. [Em Mettray] a modelagem do corpo dá lugar a um conhecimento do indivíduo, o aprendizado das técnicas induz a modos de comportamento e a aquisição de aptidões se mistura com a fixação de relações de poder [...]. Mettray é um exemplo da especificidade que lhe é reconhecida nessa operação de adestramento. (FOUCAULT, 2013, p. 279)

O ensino em Mettray desdobra e desvela a própria arte das relações de poder. Em seu interior, as práticas que visam normalizar o comportamento dos sujeitos indisciplinados foi ela própria normalizada. Normalização do poder de normalização. Curiosamente, no entanto, Mettray permaneceu, quarenta anos após a publicação de Vigiar e punir, como uma espécie de ponto cego nas análises pedagógicas.

Deixa-se ao largo algo que o pensador francês tinha como fundamental para o entendimento da escolarização em nossas sociedades disciplinares: o nascimento de uma técnica refletida das normas. Uma técnica que logo se expandiria, transportando as práticas racionalizadas da instituição penal para o conjunto do corpo social. Com Mettray, uma "rede carcerária sutil, graduada, com instituições compactas" deixaria de lançar o "elemento inassimilável" em um inferno confuso, constituindo um "grande continuum carcerário que difunde as técnicas penitenciaras até as disciplinas mais inocentes [...], e fazem pesar sobre a menor ilegalidade, sobre a mínima irregularidade, desvio ou anomalia, a ameaça da delinquência" (FOUCAULT, 2013, p. 282). Sem Mettray e o seu esforço educativo para "disciplinar os disciplinadores" daqueles que "resistem à normalização disciplinar", não conheceríamos a generalização do arquipélago carcerário, ou seja, não teríamos essa formação disciplinar, contínua e cerceadora (FOUCAULT, 2013, p. 284). A partir de Mettray, o poder disciplinar não pode mais consentir em perder sequer o que insistiu em desqualificar, tomando "por um lado, o que parece excluir por outro" (FOUCAULT, 2013, p. 285).

A sociedade domesticada, cujo exemplo-limite é Mettray, só se tornou possível porque o incorrigível deixou de estar do lado de fora da lei. Como delinquente em potencial, ele foi posto na própria essência da lei. Isso significa que o poder que sustenta o carcerário deixou de diferenciar o poder de curar ou educar. $\mathrm{Na}$ verdade, ele 
passou a receber destes uma garantia que "vem de baixo", mas nem por isso, diz Foucault (2013, p. 287), menos importante: a justificação racional do poder técnico de disciplinar.

[Assim] entre a última das instituições de 'adestramento' onde a pessoa é recolhida para evitar a prisão, e a prisão aonde ele é enviada depois de uma infração caracterizada, a diferença é mal e mal perceptível [...], apagando o que possa haver de violento em um e de arbitrário no outro, atenuando os efeitos de revolta que ambos possam suscitar [...]. (FOUCAULT, 2013, p. 286)

Essa operação foi alcançada com a colocação em cena dos novos técnicos da indisciplina, encarregados de fazer com que as "pessoas aceitassem o poder de punir", ou que, sendo efetivamente punidos, "tolerassem sê-lo" (FOUCAULT, 2013, p. 287). Mais do que uma normalização maciça, em Vigiar e punir, a análise da colônia penal de Mettray, apresentada por Foucault, nos confronta com a gênese do modo como a "indisciplina fez escola", demonstrando que o "homem conhecível" das ciências humanas e o "homem educando" das teorias pedagógicas são efeitos desse processo.

\section{INCONCLUSÕES: UM POUCO AQUÉM E UM POUCO ALÉM DE VIGIAR E PUNIR}

Então, é verdade, Foucault exagera. Sim e não. A resposta é positiva na medida em que o dispositivo carcerário, que, na modernidade, articula-se com as diversas instituições encarregadas de socorrer, curar e educar, passou a exercer um poder de normalização crescentemente generalizado. Mas, por outro lado, o autor desse livro, cuja vida foi bruscamente interrompida, já nos advertira que suas análises deveriam servir apenas como pano de fundo para diversos estudos sobre o poder de normalização.

Em outros termos, o que, de fato, preside os mecanismos de encarceramento não é "o funcionamento unitário de um aparelho ou de uma instituição", mas a "necessidade de um combate e as regras de uma estratégia" (FOUCAULT, 2013, p. 291). O ronco surdo dessa batalha, contudo, teria sua história contada apenas nos últimos cursos ditados por Foucault no Collège de France, ao abrir o ato educativo às artes da existência, dimensionando a techné tou biou como elemento da espiritualidade política ocidental.

Ao contrário daqueles que advogam pelas interpretações descontínuas das últimas pesquisas genealógicas de Foucault, cindindo suas reflexões éticas e políticas, admitimos que a chamada ética do cuidado não apenas continuou as investigações abertas em 
Vigiar e punir, como também explicitam por que sua última grande investigação genealógica publicada, sob o signo de uma história da sexualidade, abre-se com uma analítica em torno da vontade de saber. Ora, na aula de 17 de março de 1971, no seu primeiro curso no Collège de France, publicado com o título Aulas sobre a vontade de saber, Foucault (2014, p. 173) já reclamava de que "se somos submetidos a uma determinação edipiana, não é no nível do nosso desejo, e sim no nível de nosso discurso verdadeiro", tal como esse funciona nas sociedades ocidentais. Dizendo de outro modo, a história de Édipo é apenas uma signalética de certa relação da verdade com os poderes e os saberes.

Por essa razão, diz Foucault (2014, p. 145), não adianta pedir à pedagogia que traga "de volta para a luz essa ocultação" do poder da verdade de que ela é apenas um efeito indireto; essa ocultação "fundamenta sua existência e garante seu funcionamento" como um poder político com a forma da ciência e do Estado.

Assim, se é verdade que, a partir dos anos 1980, Foucault aparece travestido, ele mesmo, de uma face professoral, não é a primeira vez que ele discute a pedagogia e a escola. Desde o seu primeiro curso no Collège de France, a escola e a pedagogia se configuraram, assim como a verdade que delas emanam, como objetos privilegiados de análise. Objetos que persistem em se desconhecerem a si mesmos como sendo historicamente produzidos. Dessa forma, Foucault, de algum modo, sempre volta à pedagogia escolar porque essa nasce para manifestar a compreensão de que "é porque se detém a verdade que se tem boas leis" (FOUCAULT, 2014, p. 138), tal como na Antiguidade, ou porque ela é um espaço de aplicação das práticas de exclusão, constitutivas "da separação razão-desrazão", assim como "da oposição delinquente/não delinquente" (FOUCAULT, 2014, p. 162) na modernidade. E é porque esse estado de coisas precisa ser efetivamente subvertido que, nos anos 1980, Foucault nos faz, mais uma vez, retornar ao mundo grego, mas, dessa vez, para observar o imperativo do cuidado de si emergindo até se tornar um princípio intolerável no modo de vida errante dos cínicos.

Diógenes, o representante máximo dessa antiga Lumpenintellighenzia (PERNIOLA, 2010, p. 51), ao mesmo tempo, torna presente e atualiza a situação de tantos estudantes e intelectuais desidentificados com a escola. Curiosamente, o estilo de vida dos cínicos, como sabemos, opôs ao ponto de vista escolar um núcleo de resistência associado ao modelo animal de sobrevivência. Ao contrário daqueles que ainda julgam a condição animal como infeliz e pobre de mundo, os cínicos consideravam os animais como verdadeiros modelos 
formativos, rompendo a conexão tornada natural entre arete e Paideia, entre excelência e saber. Para eles, a virtude seria independente do conhecimento, chamando de bílis (kholé) a escola (skholé).

Mais: colocando a nu suas existências, os cínicos foram os primeiros incorrigíveis e os primeiros profanadores da escola disciplinar. Críticos ácidos de toda sociedade normalizada, eles preferem "falsificar a moeda", quer dizer, não fundar nem frequentar escolas. Logo, não é casual que tenha sido à sombra do cinismo que Foucault tenha buscado concluir sua escavação das raízes mais secretas do sentir e do pensar contemporâneo, desmascarando nossas supostas disposições humanistas e desdobrando uma nova arqueologia da escola capaz de transpor o abismo aberto pela tradição metafísicodomesticadora denunciada exemplarmente já em Vigiar e punir.

Ao repor a animalidade como um espelho de nossa própria condição indigente, os cínicos manifestaram ao genealogista uma reversão importante na vontade de saber que historicamente circunscreveu nossa "moral do delito" (FOUCAULT, 2014, p. 153), mostrando como o homem emergiu, na espiritualidade política ocidental, como um animal atravancado pela escolarização. Lição dura e impiedosa. Essa herança, ainda impensada de nossas instituições disciplinares, também parece guardar a chave do poder que a escola tem de resistir (e exceder) às suas próprias formas e obras, quando resolve abdicar da tarefa de correção ortopédica das potencialidades humanas.

Assim, colocamo-nos intencionalmente entre aqueles leitores que pretenderam "tirar conclusões do fato de um cão ter deitado no dia seguinte no lugar onde fora levantada a fogueira" que consumiu Damiens, apostando, sim, em certa dificuldade no fato de que, mesmo enxotado, esse animal tenha procurado justamente o lugar em que Damiens foi supliciado na fogueira para descansar (FOUCAULT, 2013, p. 11). Na verdade, a partir desse retorno intempestivo do animal em Vigiar e punir, procuramos mostrar que tanto o animal, como o incorrigível e os cínicos, descritos por Foucault, continuam endereçando aos educadores um convite enigmático.

Trata-se de um convite a desconfiar da existência de objetos e teleologias naturais na escola, vislumbrando nela forças reais que, embora não atuais, são possíveis de se manifestar. Pois, como lembra Paul Veyne (1995), Foucault é, antes de tudo, o pensador para quem tudo se dá pela emergência de virtualidades que ganham rosto, singularizam-se, tornamse reais. Nesse contexto, educar para a liberdade exige a conjuração de outras maneiras de viver, coragem de suspender as práticas escolares de domesticação, uma vez que se Zaratustra e Foucault não gostam 
dos homens do humanismo e de suas escolas; é porque preferem suas potencialidades, amam aquilo que ainda não veio.

Importa tanto a Zaratustra quanto a Foucault apenas o futuro dessa besta que grunhe no deserto. Uma besta estranha, pois ela mesma criou e difundiu as ferramentas com as quais se emasculou. Evocando educadores por vir, ambos vêm anunciar, com seus bestiários, uma forma extrema de cuidado de si. Exercícios espirituais na escola, sim, mas exercícios para depor nossos humanismos metafísicos, devolvendo ao livre uso aquilo que historicamente foi colocado numa esfera separada. Como sabemos, Vigiar e punir termina abruptamente com o anúncio de uma batalha, um ronco surdo. Talvez porque, na escola foucaultiana, os "cães em liberdade" já tenham se evadido, os "inumeráveis" permanecem escapando à nossa contagem, e os que "acabam de quebrar a bilha", inesperados e indiscerníveis, como os "et caetera", nunca poderão ser recenseados.

\section{REFERÊNCIAS}

AGAMBEN, Giorgio. O aberto: o homem e o animal. Rio de Janeiro: Civilização Brasileira, 2013. BARROS, João Roberto. Epimeleia heautou helenística em Foucault: universalização e espiritualidade. Prometeus, v. 5, n. 9, p. 9-25, jan./jun., 2012.

BERT, Jean-François. Comment fréquenter Foucault em historien? In: BERT, JeanFrançois; LAMY, Jérôme (Org.). Michel Foucault: un heritage critique. Paris: CNRS Éditions, 2014. p. 71-83.

DELEUZE, Gilles. Foucault. São Paulo: Brasiliense, 2006. 33 p.

DERRIDA, Jacques. O animal que logo sou: (a seguir). São Paulo: Unesp, 2002.

ESPOSITO, Roberto. El dispositivo de la persona. Buenos Aires: Amorrortu, 2011.

FOUCAULT, Michel. A poeira e a nuvem. In: FOUCAULT, Michel. Ditos \& escritos IV: estratégia, poder-saber. Rio de Janeiro: Forense Universitária, 2003. p. 323-334.

FOUCAULT, Michel. Os anormais: curso no Collège de France (1974-1975). São Paulo: Martins Fontes, 2006.

FOUCAULT, Michel. Vigiar e punir: nascimento da prisão. 41. ed. Petrópolis: Vozes, 2013. FOUCAULT, Michel. Aulas sobre a vontade de saber: curso no Collége de France (19701971). São Paulo: Martins Fontes, 2014.

GALLO, Silvio. Foucault: (re)pensar a educação. In: RAGO, Margareth; VEIGA-NETO, Alfredo (Org.). Figuras de Foucault. 2. ed. Belo Horizonte: Autêntica, 2008. p. 253-260.

GIORGI, Gabriel. Formas comunes: animalidade, cultura, bipolítica. Buenos Aires: Eterna Cadencia, 2014.

MERQUIOR, José Guilherme. Michel Foucault ou $\mathbf{O}$ nihilismo de cátedra. Rio de Janeiro: Nova Fronteira, 1985.

OLIVEIRA, Luciano. Relendo 'Vigiar e punir'. Dilemas: Revista de Estudos de Conflito e Controle Social, v. 4, n. 2, p. 309-338, abr./jun. 2011. 
PERNIOLA, Mario. Desgosto, novas tendências estéticas. Florianópolis: Editora da UFSC, 2010.

PERROT, Michele. L'impossible prison. Rechercher sur le système pénitentiaire au XIX siècle. Paris: Seuil, 1980.

SLOTERDIJK, Peter. Regras para o parque humano: resposta à carta de Heidegger sobre o Humanismo. São Paulo: Estação Liberdade, 1999.

VACCARO, Salvo. Biopolítica e zoopolítica. REU, Sorocaba-SP, v. 37, n. 2, p. 41-58, dez. 2011. VEIGA-NETO, Alfredo. Editorial. Revista Educação \& Realidade, Porto Alegre: UFRGS, v. 34, n. 2, p. 5-9, maio/ago. 2009.

VEYNE, Paul. Como se escreve a História: Foucault revoluciona a História. Brasília: Editora da UnB, 1995.

VIVEIROS DE CASTRO, Eduardo. Os pronomes cosmológicos e o perspectivismo ameríndio. Mana, Rio de Janeiro, v. 2, n. 2, p. 115-144, out. 1996.

\section{NOTAS}

${ }^{1}$ Causa-nos, portanto, estranheza certos usos das teses de Foucault, no campo educacional, nos quais sua crítica radical ao poder disciplinar se converte, quase automaticamente, numa defesa edificante em torno de uma pedagogia mais humanizadora. Esquece-se, facilmente, de que os propósitos de Foucault não eram reformistas, na medida em que ele não sonhava com uma prisão ou uma escola mais "humana".

${ }^{2}$ Foucault (2013, p. 166-178) retoma o Tratado sobre as obrigações dos Irmãos das Escolas Cristãs; discute a disposição da classe dos Colégios jesuitas; analisa a configuração da Escola dos Gobelins; tematiza as implicações do método Lancaster, e a reorganização da escola militar de Paris-Duverney.

3 As implicações éticas e políticas dessa tarefa apontam a dificuldade de uma apropriação filosófico-pedagógica tanto da corporeidade, quanto da animalidade pelas teorias educativas modernas.

${ }^{4}$ Nessa direção, mais do que interrogar se a escola é ainda um local de disciplinarização, Foucault nos convida a questionar se a escola, ela mesma, não teria se tornado um animal domesticado. Quem seriam, então, os donos da escola? Quem domesticaria a escola? Essas questões nos foram inspiradas pela leitura provocadora e polêmica do texto "Animal de muitos donos: cultura política e gestão escolar", publicado na revista Educativa, em 2008, pelos professores Jadir de Morais Pessoa e José Adelson Cruz.

${ }^{5} \mathrm{~A}$ diferença entre esses pontos de vista - e um ponto de vista não seria senão uma diferença - não residiria na alma, mas na concretude dos corpos, ou seja, nas afecções que singularizam cada espécie de corpo: o que ele come, como se move, se comunica. Todo corpo seria uma espécie de signo das diferenças de afecção, ou seja, das várias formas de estilização da existência (VIVEIROS DE CASTRO, 1996).

${ }^{6}$ Obviamente não se trata de encontrar em Vigiar e punir uma nova hermenêutica da escola, construída a partir dos olhos assombrados do animal, como em Derrida (2002), mas de abrir uma genealogia que evidencie a contingência do velho esquema aristotélico de uma dynamis sempre orientada por um telos.

${ }^{7}$ Para Foucault (2006, p. 117-120), a principal questão levantada pelos incorrigíveis diz respeito à sua imputabilidade, ou seja, sua capacidade de compreender e viver sob o domínio das leis. Como os loucos e as crianças, eles são inimputáveis, razão pela qual eles são o "inimigo da sociedade inteira". 
${ }^{8}$ Em outras palavras, a todo instante, observamos o esforço sistemático de Foucault para mostrar um longo trabalho para impor à percepção que se tinha dos delinquentes contornos bem determinados, apresentando-os como estando bastante próximos, isto é, em toda parte, devendo ser em toda parte temíveis. A produção da delinquência e seu investimento são tomados pelo que manifestam: táticas que se deslocam.

${ }^{9}$ Sugestiva também é a percepção de Foucault (2013, p. 272-273) de que essa batalha está "longe de ter triunfado", devendo, por isso mesmo, tornar-se um fenômeno melhor estudado, tanto pela importância que teve para o movimento operário, quanto para a distinção entre criminosos comuns e presos políticos; distinção que mascara "com o brilho que lhe é dado" outra criminalidade que é às vezes causa dela, ou sua: a "delinquência de cima", ou seja, a delinquência própria à riqueza e tolerada pelas leis.

${ }^{10}$ Vários comentadores, por exemplo, são enfáticos ao afirmar a centralidade do papel dos conventos cristãos, em Vigiar e punir, considerados como "o principal modelo organizativo" da "difusão das tecnologias disciplinares em colégios e fábricas". Um indício claro da articulação entre as pesquisas sobre o poder disciplinar dos anos 1970 e as análises tardias devotadas ao governo dos vivos e à ética do cuidado nos anos 1980 (BARROS, 2012, p. 23).

Submetido: 06/02/2016

Aprovado: 16/05/2016

Contato:

Av. Dolores Duran, 140 Qd. 02 Bl. 01 Apt. 305, Curado 3 - Jaboatão dos Guararapes

Recipe | PE |Brasil

CEP 54.220-140. 